\title{
Evaluate The Role of Tranexamic Acid In Joint Replacement Surgeries
}

\author{
Shreyash Yadav ${ }^{1}$,Vijendra D Chauhan ${ }^{12}$, Chetan Peshin $^{3}$ \\ ${ }^{I}$ Department of Orthopedics SRHU Swami Rama Nagar Dehradun, India \\ ${ }^{2}$ Professor, Corresponding author, Department of Orthopedics SRHU Swami Rama Nagar Dehradun, India \\ ${ }^{3}$ Assistant Professor, Corresponding author, Department of Orthopedics SRHU Swami Rama Nagar
}

Dehradun, India

\begin{abstract}
Background: Joint replacement surgeries are associated with major blood loss intra-operatively as well as post-operatively to the tune of 700 to $2100 \mathrm{ml}$. Thus generating a need for blood conservation modalities.

Material: Double blinded case control study was done for 78 patients undergoing joint replacement surgeries out of which 37 were in experimental group and 41 in control.

Results: We found a significant reduction in experimental group to an average of $150 \mathrm{ml}$ for Hemiarthroplasty, $200 \mathrm{ml}$ for Total Hip Replacement and 300ml for Total Knee Replacement.

Summary: Tranexamic Acid is a safe, efficient and a cost effective drug to control intra-operative as well as post-operative blood loss.
\end{abstract}

Keywords : Joint Replacement, Blood Loss, Tranexamic Acid

\section{Introduction}

Joint replacement surgeries are very commonly being performed even in developing countries, but these surgeries are associated with major blood loss intra-operatively as well as post-operatively to the tune of 700 to $2100 \mathrm{ml}$ (1). The soft tissues in and around the hip, notably the significant adipose tissue in the subdermal layers of the thigh, makes the patient undergoing hip replacement vulnerable to a significant amount of unrecognized blood loss during and after the operative procedure. In Total Knee Arthroplasty a tourniquet can be applied prior to the operation given the distal nature of the skin incision but the use of tourniquet leads to hyperfibrinolysis which in itself increases bleeding (2). Despite immense improvements in surgical as well as anesthetic techniques major orthopedic surgeries like joint replacement surgeries are commonly associated with marked blood loss, and a subsequent need for blood transfusion is often encountered. Bleeding causes are multifactorial, increased fibrinolytic activity being one of them (3).

Best efforts to maintain intra-operative hemostasis are taken by the treating surgeon and anesthesiologist in order to reduce bleeding into the post-operative period and for better visualization of surgical site. Unfortunately, the surgeons have no options for dealing with bleeding from vessels contained within bone, as neither electro-cautery nor suture ligation is effective at arresting the persistent oozing from cancellous bone. During Hip surgeries the femoral intramedullary canal and the periacetabular region contain a significant amount of cancellous bone which bleeds profusely leading to massive blood loss.

Other blood conservation techniques currently available are hypotensive anaesthesia, regional anaesthesia and use of erythropoietin; all of these have their own consequences and complications.Allogenic blood transfusion is currently the most effective and only available solution to compensate for blood loss but blood transfusion in itself is associated with haemolysis, immunological response activation, risks of disease transmission like (HIV, HbsAg etc.), transfusion-related acute lung injury and post-operative surgical site infection, as well as high medical costs and prolonged hospital stay. This leads to increase in cost burden to the patient. Thus creating the need for a new modality of blood conservation.

Tranexamic Acid has gained popularity in recent years to reduce this surgical blood loss in patients undergoing joint replacement surgeries.Tranexamic Acid enters the extra-vascular space around surgical site and accumulates in tissues for as long as 17 hours, being a synthetic derivative of the amino acid lysine, it exerts its anti-fibrinolytic activity by reversibly binding to plasminogen and blocking its interaction with fibrin thus delaying the dissolution of haemostatic fibrin, thereby preventing dissolution of the fibrin clots (4).The drug can be used intravenously in a weight-based manner $(10-20 \mathrm{mg} / \mathrm{kg})$, or administered $1 \mathrm{gm}$ intravenously at the start of surgery and repeated intravenously $8^{\text {th }}$ hourly for next two doses (5).Despite the proven efficacy of the use of Tranexamic Acid in total joint replacement, there are still some concerns about the development of venous thromboembolism (VTE) after Tranexamic Acid is used, however recent studies have not shown any increase in incidence of VTE or renal complications post Tranexamic Acid administration (6). 
The primary objective of this double blinded case-Control study was to evaluate the role of Intravenous Tranexamic Acid therapy in reducing total blood loss in patients undergoing joint replacement surgeries.

\section{Materials}

The present investigation was a double blinded case Control study conducted from January 2015 to January 2016. It included 78 patients coming to orthopedic OPD or Emergency undergoing joint replacement surgery for any reason. By means of simple randomization patients were divided into two groups, Experimental and Control groups. Patients having a known history of thromboembolic disease, myocardial infarction, cerebrovascular disease, angina, coagulopathy, any liver or renal disease or any other source of active bleeding were excluded from the study. Patients with pre-operative hemoglobin more than $10 \mathrm{mg} / \mathrm{dl}$ for males and $9 \mathrm{mg} / \mathrm{dl}$ for females were included in this study after an informed and written consent The Experimental group included 37 patients out of which 16 underwent Hemiarthroplasty, 12 Total Hip Arthroplasty and 9 Total Knee Arthroplasty. The Control group consisted of 41 patients out of whom 18 underwent Hemiarthroplasty, 14 Total Hip Arthroplasty and 9 Total Knee Arthroplasty.

\section{Drug Preparation and Administration:}

Operating room nursing staff prepared two syringes one containing Tranexamic Acid $(0.1 \mathrm{ml} / \mathrm{kg})$ and another containing Normal Saline $(0.1 \mathrm{ml} / \mathrm{kg})$. He had no access to the details of the patient except their IPD number and Weight. He then randomized patients and gave one of the pre-filled syringes to the Anesthetist who injected the contents of the drug intravenously slowly at a rate of $1 \mathrm{ml} / \mathrm{min}$ starting at the incision time (for Total Hip Arthroplasty or Hemiarthroplasty) of surgery or 15 minutes before Tourniquet inflation (in case of Total Knee Arthroplasty) to the patient without knowing the content of the syringe. Post-operatively same syringe content was administered to the patient at $8^{\text {th }}$ hour and at $16^{\text {th }}$ hour from incision time by post-operative room nursing staff as per order of the operating room staff assigned for this study. The details of the record were kept by the operative room staff.

\section{Method of Calculating Blood Loss:}

1. A sensitive digital weighing machine was used to measure the weight of dry mop pieces and an average weight of dry mop pieces was taken as a standard and was compared to the weight of all used blood soaked mop pieces post-surgery in each case. The dry mop weight was subtracted from soaked mop weight giving the blood loss in mop.

2. The total output in suction container was subtracted from the total amount of fluid (Normal Saline) used to wash the surgical site to calculate the blood loss in suction.

3. Spillage was approximated by the operating surgeon.

4. Amount of collection in Romovac drain was calculated post-operatively till $2^{\text {nd }}$ post-op day when drain was removed.

5. Post-operatively hemoglobin and packed cell volume were done on day 1 .

Statistical analysis was carried out using SPSS 22. Mann-Whitney U test was used to analyze the blood loss and hemoglobin of Experimental and Control group.

Tables And Results

Table 1. Patient's characteristics and their age.

\begin{tabular}{|l|c|c|c|}
\hline & Experimental & Control & P value \\
\hline No. of subjects & $\mathbf{3 7}$ & $\mathbf{4 1}$ & \\
\hline Sex (M/F) & $20 / 17$ & $20 / 21$ & \\
\hline M/F Ratio & 1.17 & 0.95 & \\
\hline Mean Age (years) & $63.16 \pm 14.6$ & $58.68 \pm 15.13$ & 0.949 \\
\hline
\end{tabular}

Table 2. Difference in intra-operative bleeding in Experimental and Control groups

\begin{tabular}{|c|c|c|c|c|c|c|}
\hline \multirow[t]{2}{*}{ Group } & \multicolumn{2}{|c|}{$\begin{array}{c}\text { Hemiarthroplasty } \\
(\mathbf{n}=34)\end{array}$} & \multicolumn{2}{|c|}{$\begin{array}{c}\text { Total Hip } \\
\text { Arthroplasty } \\
(n=26)\end{array}$} & \multicolumn{2}{|c|}{$\begin{array}{c}\text { Total Knee } \\
\text { Arthroplasty } \\
(n=18)\end{array}$} \\
\hline & Mean & SD & Mean & SD & Mean & $\mathrm{SD}$ \\
\hline Experimental & 318.40 & 28.32 & 495.18 & 71.09 & 473.93 & 51.50 \\
\hline Control & 400.33 & 57.06 & 562.09 & 119.9 & 561.89 & 88.37 \\
\hline p value & \multicolumn{2}{|c|}{$\mathrm{p}=0.000$} & \multicolumn{2}{|c|}{$\mathrm{p}=0.015$} & \multicolumn{2}{|c|}{$\mathrm{p}=0.019$} \\
\hline MWU value & \multicolumn{2}{|c|}{260} & \multicolumn{2}{|c|}{117} & \multicolumn{2}{|c|}{67} \\
\hline
\end{tabular}


Table 3. Comparison of blood loss in post-operative drain in Experimental and Control groups.

\begin{tabular}{|c|c|c|c|c|c|c|}
\hline \multirow[t]{2}{*}{ Groups } & \multicolumn{2}{|c|}{$\begin{array}{c}\text { Hemiarthroplasty } \\
(\mathbf{n}=34)\end{array}$} & \multicolumn{2}{|c|}{$\begin{array}{c}\text { Total Hip Arthroplasty } \\
(\mathbf{n}=26)\end{array}$} & \multicolumn{2}{|c|}{$\begin{array}{c}\text { Total Knee Arthroplasty } \\
(\mathbf{n}=\mathbf{1 8})\end{array}$} \\
\hline & Mean & SD & Mean & SD & Mean & SD \\
\hline Experimental & 120.93 & 38.56 & 157.50 & 57.06 & 149.44 & 51.26 \\
\hline Control & 192.77 & 60.46 & 275 & 129.54 & 361.66 & 120.36 \\
\hline P value & \multicolumn{2}{|c|}{$\mathrm{p}=0.000$} & \multicolumn{2}{|c|}{$\mathrm{p}=0.013$} & \multicolumn{2}{|c|}{$\mathrm{p}=0.000$} \\
\hline MWU value & \multicolumn{2}{|c|}{245.50} & \multicolumn{2}{|c|}{131.50} & \multicolumn{2}{|c|}{79} \\
\hline
\end{tabular}

Table 4. Total blood loss observed in Experimental and Control group in Hemiarthroplasty $(\mathrm{n}=34)$

\begin{tabular}{|c|c|c|c|}
\hline Group & \multirow{2}{*}{$\begin{array}{c}\text { No. of Cases } \\
\mathbf{N}=\mathbf{3 4}\end{array}$} & Mean & BD \\
\cline { 3 - 4 } & 16 & 439.34 & 40.80 \\
\hline Experimental & 18 & 593.11 & 60.61 \\
\hline Control & $\mathbf{p}$ value $=\mathbf{0 . 0 0 0}$ and $\mathbf{M W U}=\mathbf{2 8 8}$ \\
\hline
\end{tabular}

Table 5. Total blood loss observed in Experimental and Control group in Total Hip Arthroplasty $(n=26)$

\begin{tabular}{|c|c|c|c|}
\hline Group & $\begin{array}{c}\text { No. of Cases } \\
\text { N=26 }\end{array}$ & Mean & Blood Loss \\
\cline { 3 - 4 } & 12 & 647.68 & 85.54 \\
\hline Experimental & 14 & 842.80 & 165.06 \\
\hline Control & \multicolumn{2}{|c|}{$\mathbf{p}$ value $=\mathbf{0 . 0 0 2}$ and $\mathbf{M W U}=\mathbf{1 4 3}$} \\
\hline \multicolumn{2}{|c|}{}
\end{tabular}

Table 6. Total blood loss observed in Experimental and Control group in Total Knee Arthroplasty (n=18)

\begin{tabular}{|c|c|c|c|}
\hline Group & No. of Cases & \multicolumn{2}{|c|}{ Blood Loss } \\
\cline { 2 - 4 } & $\mathbf{N = 1 8}$ & Mean & SD \\
\hline Experimental & 9 & 623.35 & 45.35 \\
\hline Control & 9 & 923.55 & 101.47 \\
\hline \multicolumn{2}{|c|}{ MWU $=\mathbf{8 1}$ and p value $=\mathbf{0 . 0 0 0}$} \\
\hline
\end{tabular}

Table 7. Difference in pre-operative and post-operative Hemoglobin in Joint Replacement Surgeries

\begin{tabular}{|c|c|c|c|c|c|c|}
\hline \multirow{2}{*}{ Group } & \multicolumn{2}{|c|}{$\begin{array}{c}\text { Hemiarthroplasty } \\
(\mathbf{n = 3 4 )}\end{array}$} & \multicolumn{2}{c|}{$\begin{array}{c}\text { Total Hip Arthroplasty } \\
(\mathbf{n = 2 6})\end{array}$} & \multicolumn{2}{c|}{$\begin{array}{c}\text { Total Knee } \\
\text { Arthroplasty } \\
(\mathbf{n}=\mathbf{1 8})\end{array}$} \\
\cline { 2 - 7 } & Mean & SD & Mean & SD & Mean & SD \\
\hline Experimental & 1.21 & 0.36 & 1.53 & 0.52 & 1.15 & 0.53 \\
\hline Control & 1.88 & 0.63 & 2.40 & 0.89 & 2.02 & 0.75 \\
\hline $\mathrm{p}$ value & \multicolumn{2}{|c|}{$\mathrm{p}=0.001$} & \multicolumn{2}{c|}{$\mathrm{p}=0.011$} & \multicolumn{2}{c|}{$\mathrm{p}=0.019$} \\
\hline MWU value & \multicolumn{2}{|c|}{236} & 133 & \multicolumn{2}{c|}{66.5} \\
\hline
\end{tabular}

The Experimental group consisted of 37 patients while Control group consisted of 41 . The Experimental and Control were found to be matched statistically on the bases of both age and sex as shown in Table 1.Total intra-operative blood loss was significantly lower in Experimental group in all three surgeries with the significant $p$ value of 0.000 for Hemiarthroplasty, 0.015 for Total Knee Arthroplasty and 0.019 for Total Knee Arthroplasty as shown in Table 2.

The post-operative drain volume was also significantly lower in Experimental group in all surgeries considered in this study with the significant $p$ value of 0.000 for Hemiarthroplasty, 0.013 for Total Knee Arthroplasty and 0.000 for Total Knee Arthroplasty as shown in Table 3.The Total blood loss (sum of intra-operative loss and post-operative drain volume) was also found to be significantly lower in Experimental group with the $\mathrm{p}$ value of 0.000 for Hemiarthroplasty, 0.002 for Total Hip Arthroplasty and 0.000 for Total Knee Arthroplasty as shown in Table 4-6.The mean fall in hemoglobin postoperative was also calculated by subtracting the pre-operative hemoglobin from post-operative hemoglobin.

Mean fall in hemoglobin was lower in Experimental group when compared to Control group with the significant $p$ value of 0.001 for Hemiarthroplasty, 0.001 for Total Hip Arthroplasty and 0.019 for Total Knee Arthroplasty as shown in Table 7.None of the patients experienced any adverse effects of Tranexamic Acid like nausea, itching, vomiting, diarrhea etc. None of the patients developed clinical signs of Deep Vein Thrombosis or any Thromboembolic phenomenon, though none of the patients were screened for the same.

\section{Discussion}

\section{Dose and Timing of Drug Administration:}

There is a great diversity in the dose and time regimen of Tranexamic Acid in different studies ranging from single dose regimen to three dose regimen eg. Ralley FE et al (7) used a single intra-operative dose of 20 $\mathrm{mg} / \mathrm{kg}$ while Motififiard M et al (8) used two dose regimen of $500 \mathrm{mg}$ Tranexamic Acid. Hiippala ST et al (9) 
used a three dose regimen with $10 \mathrm{mg} / \mathrm{kg}$ intra-operative and two post-operative doses, Sabatini $\mathrm{L}$ et al (10) used $10 \mathrm{mg} / \mathrm{kg}$ bolus with infusion and repeat dose after 3 hours, Maniar RN et al (11) compared three different regimen (intra-operative dose before tourniquet deflation, additional pre-operative dose and additional postoperative dose) and found that minimum two dose regimen is needed for significant reduction in blood loss. Pharmacokinetic studies indicate that the therapeutic level of Tranexamic Acid stays in body for approximately 8 hours and this covers the period of hyperfibrinolysis in cases of increased blood loss (12). That is the sole reason of repeat dose at 8 hours interval in our study.

The dose regimen used in our study included $10 \mathrm{mg} / \mathrm{kg}$ dose pre-operative and repeated twice postoperatively at 8 hours interval is consistent with Niskanen RO et al (13) which showed that average blood loss in Experimental group of Total Hip Arthroplasty to be $792 \mathrm{ml}$ and in Control group it was $1102 \mathrm{ml}(\mathrm{p}=0.03)$. In our study it was $647.68 \mathrm{ml}$ and $842.80 \mathrm{ml}(\mathrm{p}=0.002)$ in Experimental and Control group respectively.Emara et al (14) compared intravenous Tranexamic Acid with placebo group and calculated total blood loss in Hemiarthroplasty to be $640 \pm 25 \mathrm{ml}$ and $1100 \pm 30 \mathrm{ml}$ in Experimental and Control group respectively with a significant value of $p<0.05$ which is consistent with our results of $439 \pm 40 \mathrm{ml}$ and $593 \pm 60 \mathrm{ml}$ with a $\mathrm{p}$ value of 0.000. Thus proving that Tranexamic Acid significantly reduces blood loss in Hemiarthroplasty.Rajesh N. Maniar et al (11) in their three dose regimen observed average blood loss of $688 \mathrm{ml}$ in Experimental and 1097 $\mathrm{ml}$ in Control group in patients undergoing Total Knee Arthroplasty with significant $\mathrm{p}$ value of 0.001 , when compared with our study in which blood loss was $623 \mathrm{ml}$ and $923 \mathrm{ml}$ in Experimental and Control group respectively with a p value of 0.000 . Our results for Total Knee Arthroplasty are consistent with their study. We found that $10 \mathrm{mg} / \mathrm{kg}$ is a sufficient dose to reduce blood loss and there is no additional benefit of increasing the dose or changing the dosage regimen.

\section{Tourniquet:}

In today's setup Total Knee Arthroplasty surgeries are done under tourniquet but many authors have stated that the application of a pneumatic tourniquet enhances fibrinolytic activity several times above the basal level in the extremity. The acceleration of fibrinolysis is due to tissue plasminogen activator released from the vascular endothelium. The release is triggered by anoxia or venous distension. It is logical to assume that this local phenomenon serves as a protective mechanism against vascular thrombosis during inflation of the tourniquet (15).

Apparently, this local acceleration of fibrinolysis and the haemostatic consequences last considerably longer and are more prone to post-operative bleeding than anticipated.

Tourniquet was used in every case of Total Knee Arthroplasty in which dose of Tranexamic Acid was given 15 minutes prior to inflation of tourniquet.

Hiippala ST et al (9) found that blood loss volume in Total Knee Arthroplasty after using tourniquet was $1509 \pm$ $643 \mathrm{ml}$ and $689 \pm 289 \mathrm{ml}(\mathrm{p}<0.0001)$, in our study it was $923.55 \pm 101.47 \mathrm{ml}$ and $623.35 \pm 45.35 \mathrm{ml}(\mathrm{p}=0.000)$ in Control and Experimental group respectively. Our results were consistent with their study with significant reduction in blood loss in Experimental group compared to Control group.We found that despite the use of tourniquet there is significant blood loss in patients undergoing total knee replacement and tranexamic acid significantly reduces the blood loss despite the use of tourniquet.

\section{Blood Loss:}

Joint replacement surgeries are associated with major blood loss. In Hemiarthroplasty it is approximated at 400-500 $\mathrm{ml}$ (16), that in Total Hip Arthroplasty is assumed to be ranging from 700-1500 ml (17) and for Total Knee Arthroplasty several authors have stated different volumes, Sehat KR et al (18) stated blood loss to be 800-1200 ml, Benoni G et al. (19) as 800-1800 ml, Georgiadis AG et al. (20) as 500-2000 ml . n Hemiarthroplasty, Emara WM et al (14) found that total blood loss with $10 \mathrm{mg} / \mathrm{kg}$ bolus dose at incision and continuous infusion of $5 \mathrm{mg} / \mathrm{kg} / \mathrm{hr}$ till end of surgery to be $640 \pm 25 \mathrm{ml}$ when compared to Control group $(1100 \pm 30 \mathrm{ml})$. In our study we found the blood loss to be $439.34 \pm 40.80 \mathrm{ml}$ in Experimental and $593.11 \pm 60.61$ $\mathrm{ml}$ in Control group. Our results are consistent with their study as there is significant reduction in blood loss in Experimental group, though there is significantly less blood loss in both groups in our study which may be due to different dose regimen used by them.

In Total Hip Arthroplasty surgeries Niskanen RO et al (13) found that there was significant reduction in blood loss (792 $\mathrm{ml}$ and $1102 \mathrm{ml}$ in Experimental and Control group respectively) by using a three dose regimen of $10 \mathrm{mg} / \mathrm{kg}$ at 0,8 and 16 hours. We found similar results with same dose regimen. In our study blood loss in Experimental group was $647.35 \pm 45.35 \mathrm{ml}$ and $923.55 \pm 101.47 \mathrm{ml}$ in Control group respectively $(\mathrm{p}=0.002)$. Our results are consistent with their study.

In patients undergoing Total Knee Arthroplasty, Iwai $\mathrm{T}$ et al (21) found that with single dose of Tranexamic Acid the blood loss was $1246.6 \mathrm{ml}$ whereas with a two dose regimen it was $915.3 \mathrm{ml}$ when compared with Control group (1538.3 ml). Hiippala ST et al (9) used $15 \mathrm{mg} / \mathrm{kg}$ dose at incision and two doses of $10 \mathrm{mg} / \mathrm{kg}$ at 
$4^{\text {th }}$ hour and $7^{\text {th }}$ hour and found the total blood loss was $1509 \pm 643 \mathrm{ml}$ and $689 \pm 298 \mathrm{ml}$ in Control and Experimental group respectively. In our study we found the blood loss to be $623.35 \pm 45.35 \mathrm{ml}$ and $923.55 \pm 101.47 \mathrm{ml}$ in Control and Experimental group respectively. Our results are consistent with their study, stating that Tranexamic Acid significantly reduces blood loss in Total Knee Arthroplasty surgeries.

\section{Hemoglobin:}

In our study we compared the fall in hemoglobin post-operatively compared to pre-operative hemoglobin and found a significantly higher hemoglobin post-operatively (Table 7) with a difference of 1.21 $\mathrm{gm} / \mathrm{dl}$ and $1.88 \mathrm{gm} / \mathrm{dl}$ in Hemiarthroplasty, $1.53 \mathrm{gm} / \mathrm{dl}$ and $2.40 \mathrm{mg} / \mathrm{dl}$ in Total Hip Arthroplasty, $1.15 \mathrm{gm} / \mathrm{dl}$ and $2.02 \mathrm{gm} / \mathrm{dl}$ in Total Knee Arthroplasty in Experimental and Control groups with a p value of 0.001, 0.011 and 0.019 respectively. Gautam PL et al (22) in their study on Total Knee Arthroplasty found the change in hemoglobin in Experimental group to be $1.06 \pm 0.46 \mathrm{gm} / \mathrm{dl}$ and in Control group was $1.94 \pm 0.55 \mathrm{gm} / \mathrm{dl}$ with $\mathrm{p}$ value of 0.01. Our results are comparable with Emara WM et al (14) for Hemiarthroplasty (average hemoglobin fall of $1.8 \mathrm{gm} / \mathrm{dl}$ and $3 \mathrm{gm} / \mathrm{dl}$ in Experimental and Control group), Hynes MC et al (23) for Total Hip Arthroplasty (average hemoglobin fall of $2.8 \mathrm{gm} / \mathrm{dl}$ and $3.8 \mathrm{gm} / \mathrm{dl}$ in Experimental and Control group), and Motififard M et al (8) for Total Knee Arthroplasty (average hemoglobin fall of $1.89 \mathrm{gm} / \mathrm{dl}$ and $2.67 \mathrm{gm} / \mathrm{dl}$ in Experimental and Control group).

Sarzaeem MM et al found that intravenous route was more effective in reducing the post-operative hemoglobin drop when compared to topical or intra-articular route (24).All these studies state that use Tranexamic Acid intravenously significantly leads to higher post-operative hemoglobin compared to placebo which is consistent with our study. A minimum of two dose regimen should be administered to significantly reduce blood loss volume. When we compared our study with other studies we found that the best regimen for most reduction in blood volume is a three dose regimen with dose of $10-15 \mathrm{mg} / \mathrm{kg}$.

\section{Strength and Limitation of Study:}

Our study included Hemiarthroplasty, total hip and Total Knee Arthroplastys while most of the authors only include one surgery. We compared each surgery with its Experimental and Control group as surgical exposure is different for all surgeries. All surgeries were performed by two specialized surgeons of same stature. Surgical time was almost same in both groups of same replacement surgery.There are a few limitations in our study, small sample size being one of them. Secondly, patients were not screened for complications like deep vein thrombosis or venous thromboembolism. Cost benefit ratio was also not calculated.

\section{Conclusion}

Tranexamic acid is an effective, efficient and a cheap drug for conservation of blood loss. It can reduce blood loss in all Orthopaedic surgeries without increasing cost burden on patient. It can also provide a better visual field due to reduced bleeding.

\section{References}

[1]. Hays MB, Mayfield JF. Total blood loss in major joint arthroplasty. A comparison of cemented and noncemented hip and knee operations.J Arthroplasty 1988;3:S47.

[2]. Klenerman L, Chakrabarti R, Mackie I et al: Changes in haemostatic system after application of a tourniquet. Lancet, 1977; 1: 9702

[3]. Sculco TP. Global blood management in orthopedic surgery. Clin Orthop Relat Res. 1998:357:43-9.

[4]. Buckwalter JA, Saltzman C, Brown T: The Impact of Osteoarthritis. Clinical Orthopedics and Related Research. 2004;427:S6-15.

[5]. Maurizio M and Paul RJA. Congenital platelet disorders in: A Victor Hoffbrand(ed) Postgraduate Haematology, $7^{\text {th }}$ edition. West Sussex, JohnWiley \& Sons, Ltd; 2011. p.761-72.

[6]. Poeran J, Rasul R, Suzuki S, Danninger T, Mazumdar M, Opperer M, et al. Tranexamic Acid use and post-operative outcomes in patients undergoing total hip or knee arthroplasty in the United States: retrospective analysis of effectiveness and safety. BMJ. 2014;349:51.

[7]. Ralley, F. E., Berta, D., Binns, V., Howard, J., \& Naudie, D. D. R. One Intra-operative Dose of Tranexamic Acid for Patients Having Primary Hip or Knee Arthroplasty. Clin Orthop Relat Res. 2010;468(7):1905-11.

[8]. Motififard M, Tahririan MA, Saneie M, Badiei S, Nemati A. Low Dose Peri-operative Intravenous Tranexamic Acid in Patients Undergoing Total Knee Arthroplasty: A Double-Blind Randomized Placebo Controlled Clinical Trial. Journal of Blood Transfusion.Volume 2015;30: 51-56.

[9]. Hiippala ST, Strid LJ, Wennerstrand MI, Arvela JV, Niemelä HM, Mäntylä SK, Kuisma RP, Ylinen JE. Tranexamic Acid radically decreases blood loss and transfusions associated with Total Knee Arthroplasty. Anesth Analg. 1997 ;84 (4):839-44.

[10]. Sabatini L, Atzori F, Revello S, Scotti L, Debiasi F, Massè A. Intravenous use of Tranexamic Acid reduces post-operative blood loss in Total Knee Arthroplasty. Arch Orthop Trauma Surg. 2014; p23-7.

[11]. Maniar RN, Kumar G, Singhi T, Nayak RM, Maniar PR. Most effective regimen of Tranexamic Acid in knee arthroplasty: A prospective randomized Controlled study in 240 patients knee. Clin Orthop Relat Res. 2012;470(9):2605-12.

[12]. Howes JP, Sharma V, Cohen AT. Tranexamic Acid reduces blood loss after knee arthroplasty. J Bone Joint Surg Br. 1996;78:9956.

[13]. Raimo O Niskanen \& Olli L Korkala. Tranexamic Acid reduces blood loss in cemented hip arthroplasty: A randomized, doubleblind study of 39 patients with osteoarthritis, Acta Orthopedica, 2005;76:6, 829-32. 
[14]. Emara, W. M., Moez, K. K., \& Elkhouly, A. H. (2014). Topical versus intravenous Tranexamic Acid as a blood conservation intervention for reduction of post-operative bleeding in Hemiarthroplasty. Anesthesia, Essays and Researches, 8(1), 48-53.

[15]. Petaj1 J, Myllynen I, Myllyla G, Vahtera E. Fibrinolysis after application of a pneumatic tourniquet. Acta Chir Stand 1987; 153:64751.

[16]. Ahn J, Man L-X, Park S, Sodl JF, Esterhai JL. Systematic review of cemented and uncemented Hemiarthroplasty outcomes for femoral neck fractures. Clin Orthop Relat Res 2008;466 (10):2513-8.

[17]. Bierbaum, B. E. et al: An analysis of blood management in patients having a total hip or knee arthroplasty. JBJS [Am]1999, 81A(1): 2-10.

[18]. Sehat KR, Evans RL, Newman JH. Hidden blood loss following hip and knee arthroplasty.Correct management of blood loss should take hidden loss into account. J Bone Joint Surg Br. 2004;86:561-5.

[19]. Na HS, Shin HJ, Lee YJ, Kim JH, Koo KH, Do SH. The effect of Tranexamic Acid on blood coagulation in Total Hip Arthroplasty arthroplasty: Rotational thromboelastographic analysis. Anaesthesia. 2016;71(1):67-75.

[20]. Georgiadis AG, Muh SJ, Silverton CD et al: A prospective double-blind placebo Controlled trial of topical Tranexamic Acid in Total Knee Arthroplasty. J Arthroplasty, 2013; 28(8): S78-82.

[21]. Iwai T, Tsuji S, Tomita T, Sugamoto K, Hideki Y, Hamada M. Repeat-dose intravenous Tranexamic Acid further decreases blood loss in Total Knee Arthroplasty. Int Orthop. 2013;37(3):441-5.

[22]. Cap AP, Baer DG, Orman JA, Aden J, Ryan K, Blackbourne LH. Tranexamic Acid for trauma patients: a critical review of the literature. J Trauma. 2011;71:S9-14.

[23]. Hynes MC, Calder P, Rosenfeld P, Scott G. The use of Tranexamic Acid to reduce blood loss during Total Hip Arthroplasty: An observational study. Ann R Coll Surg Engl. 2005;87(2):99-101.

[24]. Sarzaeem MM, Razi M, Kazemian G, Moghaddam ME, Rasi AM, Karimi M. Comparing efficacy of three methods of Tranexamic Acid administration in reducing hemoglobin drop following Total Knee Arthroplasty. J Arthroplasty. 2014;29(8):1521-4. 